\title{
DEVELOPMENT OF ORGANIC FARMING IN POLAND AFTER 2013 IN TERMS OF COMMON AGRICULTURAL POLICY
}

\author{
Alicja Kasperowicz-Stępień \\ Doctor of Economic Sciences \\ Finance Department \\ Cracow University of Economics \\ 27 Rakowicka str., Cracow, Poland, 31-510 \\ kasperoa@uek.krakow.pl \\ Katarzyna Stabryla-Chudzio \\ Doctor of Economic Sciences \\ Finance Department \\ Cracow University of Economics \\ 27 Rakowicka str., Cracow, Poland, 31-510 \\ stabrylk@poczta.onet.pl
}

\begin{abstract}
Organic farming in the European Union is still a small percentage, but there is a noticeable upward trend, albeit mainly in the countries of the old EU (EU-15). At the same time, according to Eurostat data and taking into account the average for the European Union, organic farms are larger than conventional farms, as well as the average age of organic farmers is lower. As a result, organic farming (biological, organic) as a system of permanent self-sustaining and economically sustainable safe management of plant and animal production should be an important alternative to conventional agriculture. In addition, efforts to develop organic farming create the capacity to deal with environmental, animal welfare and rural development, while producing high quality food.

The aim of the paper is to provide opportunities for development of organic farming in Poland in the light of EU regulations for the years 2014-2020.

Keywords: organic farming, Framework Action Plan for Organic Food and Farming in Poland, organic farms in Poland and in the EU, legal regulations development of organic farming, control and certification system for organic farming.

\section{Introduction}

According to the Framework Action Plan for Food and Farming in Poland for years 2014-2020, organic farming (biological, organic) means a system of sustainable and economically self-sufficient, safe management of sustainable plant and animal production on the farm. Development of organic agriculture offers opportunities to solve problems related to environmental protection, animal welfare and rural development, while producing high-quality food [1].

The most important documents, which set out the objectives and actions necessary for the development of organic farming in Poland include: Framework Action Plan for Food and Farming in Poland in the years 2014-2020 referring to the National Development Strategy 2020, to the Strategy for Sustainable Rural Development, Agriculture and Fisheries on years 2012-2020 and the Rural Development Programme 2014-2020. It should be noted that the national documents have been prepared in accordance with EU regulations relating to the common agricultural policy.

The aim of this paper is to present the possibilities of development of organic farming in Poland in the light of provisions of the EU for the period 2014-2020. According to the European Commission prospects for the sector of agriculture is promising, provided a skillful combination of actions to stimulate the market (growth of supply and demand) and to enhance the credibility the whole system of organic farming which leads to the increase of consumer confidence [1].

\section{Organic farming in the European Union}

Organic farming in the Community activities was singled out in the early 90 -th years of 20 century as part of the reform of agricultural policy. Under the regulation adopted by the minis- 
ters of agriculture in 1991 it was prepared the definition of organic farming and the principles of organic farming, including labels associated with organic production. It was also specified the rules allowing the import of organic products from countries outside the European Union. Initially, the guidelines related to production of plant, and then the products of animal origin (mainly animal nutrition, protection against diseases, breeding and animal husbandry, veterinary protection and use of natural fertilizers). The purpose of this adjustment was to allow EU citizens to acquire organic products in accordance with common standards. Also it allowed the possibility of applying stricter criteria, if that was the will of national governments or private organizations [2].

The importance of organic farming in the European Union is growing from year to year. According to the Council Regulation No 834/2007 of 28 June 2007, organic agriculture plays the dual social function, because [3]:

- firstly, it provides high quality food with safe and important sensory qualities;

- secondly, it contributes to the protection of the natural environment, animal welfare and rural development.

The current rules are not transparent, and also increasingly difficult to reconcile the growing expectations of consumers with more stringent administrative requirements for farmers who want to lead an organic farm [4, 5]. As a result, in 2014 there were proposals for new regulations [6], to ensure the sustainability of farming activities, competition rules for the proper functioning of the internal market and the increase in consumption of organic products resulting from the growing consumer confidence in these products. Possible changes could come into force in July 2017 and among them should be mentioned first of all, the proposal to carry out group certification for small farmers in order to reduce the administrative costs of control and certification, the development of electronic system of certification, standardization of control provisions (elimination of most exemptions and exceptions and take control of all actors in the ecological chain).

Consultations with international experts and the public consultation took place in 2012-2013, and the topic of changes in the regulations on organic farming triggered an in-depth discussion on the future of organic production [7]. Numerous criticisms from agricultural communities, organizations and individual farmers on the proposed Regulation may, however, to convince the European Commission to the need for preparation of a new solution. Among the requested modification can include, for example suggestions to take into account to a greater extent the interests of not only large companies but also small producers and the diversity and regional specificities within the European Union.

As part of the multiannual financial framework for 2014-2020, the European Commission has prepared a number of financial incentives to encourage farmers have to carry an organic farm or a farm with environmental protection. The European funds for the development of organic farming in the European Union are not only guaranteed within the category: Sustainable growth: natural resources, but also in the category of Intelligent growth in programme Horizon 2020. The European Commission supports research on improving e. g. soil fertility, innovative methods of protection against pests, diseases and weeds, suitable alternatives to products containing copper used for environmental protection products, animal feed, feed efficiency, energy use, soil conservation, climate change and reduce energy consumption by greenhouses [1]. It is mainly about the research in international teams (consortia), awareness of EU organic scheme including the EU organic logo, and above all, the application of research results in practice.

By $201530 \%$ of direct payments are related to the so-called requirement, greening, or crop diversification, maintenance of permanent grassland and ecological protection areas within farms. A holding covers more than 15 hectares must represent in the future $7 \%$ of arable land and may include, among others, [8]: land laying fallow, terraces, strips of eligible hectares along forest edges, buffer strips, including buffer strips covered by permanent grassland, areas with short rotation coppice with no use of mineral fertilizer and/or plant protection products, afforested areas, areas with catch crops, or green cover established by the planting and germination of seeds.

Within the second pillar of the Common Agricultural Policy included measures for existing farmers with organic farms and for those who want to turn activity in conventional adequate for organic farming. The Regulation on rural development [9] clearly states that Member States meet the 
expectations of consumers and society in general, should support the conversion of farms and the maintenance of existing ones. Financial support is intended to cover all or part of the income lost (through loss of yield value) and/or additional costs (e. g. fuel), which arose as a result of the commitments. In the framework of rural development programs, each EU country has the flexibility to finance the other projects that may be associated with organic farms, e. g. in the field of innovation, counseling, support groups, producers, environmental protection and counter climate change, improve the quality of food as well farm modernization (purchase of machinery, equipment, tools, modernization of buildings, structures used for agriculture).

\section{Status of organic farming in Poland compared to other European Union countries}

The area of organic farmland in the European Union in late 2014 accounted for 10.3 million hectares, or $5.7 \%$ of total agricultural land. It is worth noting that since 2004 , after the accession of new members to the EU, there has been a 76 percent increase in organic farmland (5.8 million ha in 2004 to 10.3 million ha in 2014). These farms were run by approx. 260 thousand manufacturers. The largest area of organic farms in absolute terms had Spain (1.7 million ha), Italy (1.4 million ha), France (1.1 million ha) and Germany (1.0 million ha), while the percentage in relation to the total agricultural land Austria (19.4\%), Sweden (16.4\%) and Estonia (16.2\%). The biggest growth area of ecological compared to 2013 were recorded in Spain (100 $346 \mathrm{ha}$ ) and the rest of the increase was much lower in Italy (70 736 ha), France (58 088 ha), Slovakia (22459 ha) and Bulgaria (18 064 ha). Otherwise the situation was, if one takes into account the percentage increase, namely in relation to the existing area in 2013. Here, the biggest increase was recorded in Malta (381\%) followed by Bulgaria (32\%) and Croatia (23\%) (Table 1).

Table 1

Countries of the European Union with the largest area of organic selected crops in 2014 (in ha)

\begin{tabular}{cc}
\hline Type of crops & Countries \\
\hline cereals & Italy, Germany, Spain, France \\
vegetables & Poland, Italy, France \\
oilseeds & Romania, France, Austria \\
grapes & Spain, Italy, France \\
temperate fruits & Poland, Italy, France \\
protein crops (dried pulses) & France, Spain, Italy
\end{tabular}

Source: own study based on: Organica Data Network-FIBL-AMI Survey 2016 based on national data and Eurostat [Willer, Schaack 2016; Lernoud, Willer 2016]

In 2014, Germany and France were respectively second and third in the world (after the United States) in terms of organic food sales reaching - 7.9 and 4.8 billion, the market for organic products in the EU reached 23.9 billion. And the largest consumption of organic foods in excess of 100 EUR per capita were recorded in Luxembourg (164 EUR), Denmark (162 EUR), Sweden (145 EUR) and Austria (127 EUR) [10, 11].

For countries that joined the EU after 2003 the Common Agricultural Policy in the field of organic agriculture has given impetus to the development, but used a different extent (significant differences are seen in the area of organic farming, production and consumption). The highest increase was mentioned above in Malta, Bulgaria, and interestingly, Croatia, which became an EU member only in 2013 [12, 13]. In Poland (Table 2), as well as in Cyprus, Hungary, Lithuania and Romania it could be observe a decrease in the area of organic agricultural land in 2014 compared to the previous year.

According to the Ministry of Agriculture and Rural Development on 30 November 2014, the certification bodies controlled nearly 26.3 thousand organic producers, of which $97.6 \%$ were farms [14-17]. Statistical data on the number of organic farms and usable in the years 2007, 2010 and 2014 is presented in Table 3. 
Table 2

Organic farming in Poland compared to other European Union countries in 2014

\begin{tabular}{|c|c|c|}
\hline & Data & $\begin{array}{l}\text { Place in comparison to other } \\
\text { countries of the European Union }\end{array}$ \\
\hline Organic area (under conversion and certified) & 657902 ha & 5 \\
\hline Share of organic agricultural land & $4,3 \%$ & 16 \\
\hline Number of producers & 24829 & 4 \\
\hline Retail sales value (m EUR)* & 120 & 12 \\
\hline Retail sales: share value & $0,2 \%$ & b. d. \\
\hline Number of processors & 484 & 14 \\
\hline Number of importers & 68 & 8 \\
\hline
\end{tabular}

Note: * data from 2011

Source: own study based on: Organica Data Network-FIBL-AMI Survey 2016 based on national data and Eurostat [Willer, Schaack 2016]

Table 3

Organic farms in Poland in selected years

\begin{tabular}{cccc}
\hline & $\mathbf{2 0 0 7}$ & $\mathbf{2 0 1 0}$ & $\mathbf{2 0 1 4}$ \\
& \multicolumn{1}{c}{ Certified } & & 21020 \\
Farms & 6618 & 32901 & 555898 \\
\hline Agricultural land of organic farms in ha & 137891 & 308095 & 3809 \\
\hline Farms & Under conversion & 7681 & 102004 \\
\hline Agricultural land of organic farms in ha & 5252 & 210974 & 24829 \\
\hline Farms & 150380 & & 657902
\end{tabular}

Source: own study based on: Roczniki statystyczne rolnictwa 2014, 2015, H. Dmochowska (red.), Gtówny Urząd Statystyczny, Warszawa 2014, 2015, p. 136, p. 117

\section{The system of control and certification of organic farms}

Organic production takes account of natural systems and cycles of nature. This is about the management of a properly balanced without (or specified conditions) the use of the organic food chemical fertilizers, pesticides, growth stimulants and preservatives, and the farming and animal husbandry - antibiotics and growth hormones [5]. Exceptionally, however, synthetic materials may be acceptable if there are no suitable alternatives. Such products, which must be examined by the Commission and EU countries prior to authorization, are listed in the Annex to Implementing Regulation [4].

Control of organic farming in the European Union refers to the process of production, processing and trade. The organic farm ought be checked taking into account: the location of the farm, buildings, structures, machinery and equipment, selected crops, livestock conditions, 
storage conditions, among others, animal feed and fertilizers. However, in processing plants is analyzed above all current documentation, the results so far of control, recipe and production standards [18].

Polish control and certification system for organic farming is one of the mixed systems, i. e. there are the control bodies of the public administration and private certification bodies (Table 4), which operate on the basis of the following principles [12]:

- confidentiality of information obtained during the inspection;

- broadly defined transparency, i. e. on the control criteria (what will be controlled), control methods (how it will be control), labeling of organic products;

- openness and voluntary - any entity interested in ecological crops and produce can become involved in organic farming; ventional;

- transparency for consumers, that is, the ease to distinguish organic products from con-

- independence of the inspectors - prohibition control in familiar farms;

- efficiency with the relationship of costs incurred during the preparation of the farm to control and income derived from production.

Table 4

The control system for organic farming in Poland

\begin{tabular}{|c|c|c|c|}
\hline \multicolumn{4}{|c|}{$\begin{array}{l}\text { Minister of Agriculture and Rural Development } \\
\text { s to carry out inspections and issue and withdraw certificates of compliance in organic farming }\end{array}$} \\
\hline \multicolumn{4}{|c|}{$\begin{array}{l}\text { Quality Inspection of Agricultural and Food } \\
\text { supervises the certification bodies and organic production }\end{array}$} \\
\hline \multicolumn{4}{|c|}{ Cooperation with: } \\
\hline Trade inspection & Veterinary inspection & $\begin{array}{l}\text { State Inspection for Plant } \\
\text { Protection and Seed }\end{array}$ & Polish Centre for Accreditation \\
\hline & Certi & Bodies & 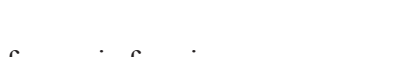 \\
\hline
\end{tabular}

Source: own elaboration based on The report on the status of organic farming in Poland in 2011-2012, Zdrojewska I. (ed.), Quality Inspection of Agricultural and Food, Warsaw 2013 www.minrol.gov.pl available. 01/10/2015 [18]

With the EU budget is financed information and promotion campaigns on organic farming to improve awareness of producers, processors, retailers and consumers in the definition of organic farming and relating to carried out activities of control and the use of the EU logo for organic farming.

In this way, the European Commission wishes to encourage the conduct of organic farms, as well as the production and sale of organic food. Promotional activities include advertising in the media (television, radio, newspapers, Internet), information at points of sale, presentations at fairs, exhibitions and educational activity for adults and children, as increased confidence and consumer interest in organic food should result in an increase in demand [19].

In view of the higher price of food products from organic farms resulting from labor-intensive and often the initial lower yields than conventional farming, campaigns usually lists the following benefits of organic farming [18]:

- protection of natural resources (including energy saving, protecting and enhancing ecosystems, ensuring the fertility of the soil);

- proper treatment of animals and livestock in appropriate conditions;

- to contribute food security through the production of healthy food and high quality;

- high self-sufficiency expressed in the use of reusable objects, natural feed and fertilizers and the use of regional and local varieties of plants and animal species; 
- partial use of the surplus labor force in rural areas;

- increase the attractiveness of settlement areas and rural tourism;

- increase the competitiveness of producers and processors of agricultural;

- broad spectrum of activity due to production for local markets, regional, national and abroad.

\section{Directions of financial support for organic farming in Poland}

The main objective set out in the Framework Action Plan for Food and Farming in Poland for the years 2014-2020 is the development of organic farming and organic food market. The main objective consist of the specific objectives and actions implemented by the Ministry of Agriculture and Rural Development, the units subordinated to or supervised, which in turn are linked to financial support in the framework of the Rural Development Programme for 2014-2020 (Table 5).

\section{Table 5}

The specific objectives and actions set out in the Framework Action Plan for Food and Farming in Poland for the years 2014-2020

\section{Specific objectives}

Actions crease the supply of organic food market

II. Stimulating the development of the processing of organic products

III. Diversification and strengthening distribution channels for organic products

IV. Increase of consumers knowledge in the area of organic agriculture and organic food

$\mathrm{V}$. Raising the level of cooperation between stakeholders in the organic sector

VI. Inclusion of central and local government into the develop-
I. Increasing the competitiveness of organic farming and inment of the organic farming sector

a) Continuation of support for organic production as part of the RDP 2014-2020 allows to reduce production costs

b) Conducting research aimed at improving production technology

c) Transfer of good practices and advisory activities

d) Reduce the need for derogation from the rules of organic production

a) Stimulate the development of the processing

b) Transfer of good practices in manufacturing

a) Development of markets and bazaars

b) Diversification of distribution channels

a) Promotion of organic food

b) Cooperation with organizations for the promotion of organic food

a) Support the integration process of industry

b) Support the process of communication between market players.

a) Cooperation with local government units

b) Cooperation with entities operating on the market of organic products

c) Green public procurement

a) Actions perfecting

VII. Maintaining a high level of system control and certification b) Transfer of good practices for the control and certification in of organic products.

rganic farming

c) Reducing real costs of inspection and certification

Source: Framework Action Plan for Food and Farming in Poland for the years 2014-2020, Ministry of Agriculture and Rural Development, Warsaw 2014, pp. 30-33

Framework Action Plan for Food and Farming in Poland for the years 2014-2020 is a necessary complement to the strategy for sustainable development of rural, agriculture and fisheries in the context of food and farming, in which distinguished the actions of particular importance from the point of view of the development of organic farming and organic food market (Table 6). 


\section{Table 6}

Activities related to organic farming and the organic food market contained in the Strategy for sustainable rural development, agriculture and fisheries

\section{Objective 3 - Food security}

Priority 3. 1. - Maintain and improve the quality of agricultural production base and fishing

Priority 3. 2. - Production of high-quality, safe consumer food products

Priority 3. 3. - Compliance / applie cation of the rules of fair competition in the Community and the global agri-food market

Priority 3. 4. - Raising awareness and knowledge of producers and consumers in the field of agri-food production and nutrition rules
Maintaining agricultural land in good agricultural condition, to preserve the land ready for production while taking into account the requirements of the environment; preservation of the genetic basis of crop production due to the values resulting from the tradition and culture of rural areas and the need to protect valuable varieties of crops and plants associated with these crops

Support the production of high-quality agri-food products, including products produced organically and traditional methods of production using local raw materials and resources and fish products

Preventing unfair practices occurring in the market related to the marketing of products of low quality and nutritional value, which are often not labeled, the application of uniform rules on competition in the EU market (to allow the producers to connect into the national and international groups)

To promote the knowledge of healthy eating and the development of proper eating habits (including the dissemination of information on the principles of nutrition and the impact of diet on health, deepening knowledge of consumers on the quality, features and advantages of high-quality agri-food products, including produced organically and traditional), information campaigns for organic products characterized by high quality and safety of the health of consumers, promotion of national and local organic food at home and abroad; work for the inclusion of information about organic food into school curricula; training for farmers concerning the principles of food safety and food production methods accordance with the approved quality system and other activities of an educational nature for manufacturers in the production of high-quality food

\section{Objective 4 - Increase productivity and competitiveness of the agri-food sector}

Priority 4. 1. - Modernization and innovation agri-food sector (e.g. processing)

Priority 4. 3. - Adaptation of structures agri-food sector to the changing challenges in Poland, the EU and globally

Priority 4. 4. - Promoting and expanding markets for agricultural and food products

\section{Objective 5 - Environmental protection and adaptation to climate change in rural areas}

Priority 5. 1. - Protection of the envie ronment in the agricultural sector and biodiversity in rural areas

Direct action for the protection of the quality of soil and water (including the rehabilitation of degraded and devastated soils, rational use of water resources, construction or repair of equipment used for drainage of water retention and water level control), public education and farmers training in agriculture ecological

Priority 5. 3. - Adaptation of agriculture and fisheries to climate Supporting the development of renewable energy, appropriate soil management, playback change and their participation in the damaged by natural disasters forestry production potential fight against these changes

Priority 5. 4. - Sustainable forest maa nagement and hunting in rural areas

Afforestation integrated with conducting organic farming

Source: own elaboration based on: Resolution No. 163 of the Council of Ministers dated April 25, 2012. On the adoption of the „Strategy for Sustainable Rural Development, Agriculture and Fisheries” 2012-2020 (M. P. of 2012. Pos. 839) [21]

According to the financial possibilities arising from the findings in the framework of multi-annual plans of the European Union, organic farming received a separate action in the Rural 
Development Programme for 2014-2020, additionally for the organic farming important may also be other activities [20]:

a) cooperation (within the operational groups for innovation only to projects of an innovative character);

b) creating groups and producer organizations;

c) transfer of knowledge and information activity (sub-measure support for vocational training and skills acquisition);

d) consulting services, services in the field of agricultural farm management and services for substitutions (sub: support for using advisory services);

e) development of households and business (sub: help to start a business for young farmers and start-up aid economic development of small farms);

f) investments in fixed assets (aid for investments in farms and investments in processing / marketing and development of agricultural products);

g) basic services and village renewal in rural areas (sub-investment related to creation, improvement or expansion of all types of small scale infrastructure, including investments in renewable energy and energy saving);

h) systems of quality agricultural products and foodstuffs (sub-measure support for new participants in food quality schemes and support to carry out the information and publicity);

i) support for local development in the framework of LEADER (sub-measure Support for the implementation of operations under local development strategies driven by the community);

j) agri-environment action-climatic.

The beneficiary of action “Organic Farming” RDP 2014-2020 will be able to be professionally active farmer holding a farm located on Polish territory, with an area of agricultural land of not less than $1 \mathrm{ha}$, which is committed to the implementation of organic farming for a period of five years and compliance with the requirements of the individual packages/organic variants.

The full amount of the payment (Table 7) get farmers with holdings up to 50 hectares, and over 50 ha value of the subsidy is reduced to $75 \%$, and the owners of more than 100 ha receive $60 \%$ of the basic amount. Thus introduced degressivity results from the study, according to which, together with the increase in area of the farm, they reduce the fixed costs and certain transaction costs (e. g. depreciation of newly acquired specialized machinery, hire specialized machinery, the purchase of specialized means of production).

Table 7

Payment during the conversion period and to maintain the ecological farm (in zł0/ha)

\begin{tabular}{ccc}
\hline & During the conversion period & After a period of conversion \\
\hline Crop farming & 966 & 792 \\
Vegetable cultivation & 1557 & 1310 \\
Herbs cultivation & 1325 & 1325 \\
Crop Orchard & & 1501 \\
- basic; & 1882 & 660 \\
- extensive & 790 & 559 \\
Forage & 787 & 428
\end{tabular}

Source: Rural Development Programme for 2014-2020 [2014], the Ministry of Agriculture and Rural Development, Warsaw, pp. 560-574

\section{Summary}

Organic farming in the European Union, including Poland, is still a small percentage, but there is a noticeable upward trend, although mainly in the countries of the so-called old Union (EU-15). At the same time, according to Eurostat, taking into account the average size of farms, 
organic farms in the European Union are larger than conventional farms, as well as the average age of organic farmers is lower.

Polish organic farming has a good basis for further development, and the European Union as a whole excels in statements relating to organic production, area of organic farmland and organic food sales. The reasons for this state of affairs include: the growing domestic demand for organic food, common regulations concerning the production and organic food, and thus the specific requirements of organic farming and related determinations [21].

As a result, EU policy in the field of organic farming impacted on national legislation and further financial support from the EU budget is an important impetus for converting conventional farms to organic, and to maintain existing of such farms. Unfortunately, the Action plan for the future of organic farming in the European Union from 2014 year does not include the transformation of the general goals into specific objectives and well-defined plan for their implementation.

\section{References:}

[1] Action Plan for the future of Organic Production in the European Union (2014), communication from the Commission to the European Parliament, the Council, the European Economic and Social Committee and the Committee of the Regions, COM (2014) 179 final, Brussels.

[2] European Commission. Agriculture and Rural Development. Organic Farming. Available at: http://ec.europa.eu/agriculture/organic/index_en.htm 28.06.2015.

[3] Council Regulation (EC) No 834/2007 of 28 June 2007 on organic production and labeling of organic products and repealing Regulation (EEC) No 2092/91 (OJ L 189 from 20.07.2007).

[4] Commission regulation (EC) No 889/2008 of 5 September 2008 laying down detailed rules for the implementation of Council Regulation (EC) No 834/2007 on organic production and labelling of organic products with regard to organic production, labelling and control (OJ L 250 from 18.9.2008).

[5] Domagalska, J., Buczkowska, M. (2015). Rolnictwo ekologiczne - szanse i perspektywy rozwoju. Problemy Higieny i Epidemiologii, 96 (2), 370-376.

[6] European Commission proposal (2014). Regulation of the European Parliament and the of Council on organic production and labeling of organic products amending regulation (EU) No XXX/XXX of the European Parliament and the of Council [Official controls regulation] and repealing Council regulation (EC) No 834/2007, COM (2014) 180 final, Brussels.

[7] Produkcja ekologiczna (2014). Wniosek Komisji na rzecz rozwoju doskonalszego rolnictwa ekologicznego, komunikat prasowy, Komisja Europejska, Bruksela.

[8] Dmochowska, H. (Eds.) (2015). Roczniki statystyczne rolnictwa 2014, 2015. Główny Urząd Statystyczny, Warszawa.

[9] Regulation (EU) No 1307/2013 of 17 December 2013 of the European Parliament and the of Council establishing rules for direct payments to farmers under support schemes within the framework of the common agricultural policy and repealing Council Regulation (EC) No 637/2008 and Council Regulation (EC) No 73/2009 (OJ L 347 from 20.12.2013).

[10] Lernoud, J., Willer, H. (Eds.) (2016). Current Statistics on organic Agriculture Worldwide: Organic Area, Producers, Markets and Selected Crops. The World of Organic Agriculture. Statistics and Emerging Trends 2016, FIBL-IFOAM Report, Research Institute of Organic Agriculture (FIBL), Frick, and IFOAM - Organics International, Bonn. Available at: http://www.organic-world.net/yearbook/yearbook-2016/ pdf.html 10.05.2016.

[11] Willer, H., Lernoud, J. (Eds.) (2016). The World of Organic Agriculture. Statistics and Emerging Trends. FIBL-IFOAM Report, Research Institute of Organic Agriculture (FIBL), Frick, and IFOAM Organics International, Bonn. Available at: http://www.organic-world.net/yearbook/yearbook-2016/pdf.html 10.05.2016.

[12] European Commission. Available at: http://ec.europa.eu/euro/index_en.html 14.01.2016

[13] Willer, H., Schaack, D., Lernoud, J. (Eds.) (2016). Organic Farming and Market Development in Europe. The World of Organic Agriculture. Statistics and Emerging Trends, FIBL-IFOAM Report, Research 
Institute of Organic Agriculture (FIBL), Frick, and IFOAM - Organics International, Bonn Available at: http://www.organic-world.net/yearbook/yearbook-2016/pdf.html 10.05.2016.

[14] Ramowy Plan Działań dla Żywności i Rolnictwa Ekologicznego w Polsce na lata 2014-2020 (2014). Ministerstwo Rolnictwa i Rozwoju Wsi, Warszawa.

[15] Regulation (EU) No 1305/2013 of 17 December 2013 of the European Parliament and the of Councilon support for rural development by the European Agricultural Fund for Rural Development (EAFRD) and repealing Council Regulation (EC) No 1698/2005 (OJ L 347 from 20.12.2013).

[16] Willer, H., Lernoud, J. (Eds.) (2016). The World of Organic Agriculture. Statistics and Emerging Trends. FIBL-IFOAM Report, Research Institute of Organic Agriculture (FIBL), Frick, and IFOAM - Organics International, Bonn, ISBN FIBL 978-3-03736-271-6, ISBN IFOAM 978-3-944372-12-9. Available at: http://www.organic-world.net/yearbook/yearbook-2016/pdf.html 10.05.2016.

[17] Ministerstwo Rolnictwa i Rozwoju Wsi ul. Wspólna 30; 00-930 Warszawa. Available at: http:// www.minrol.gov.pl 3.08.2015

[18] Miśniakiewicz, M. (2005). Rolnictwo ekologiczne w Polsce - regulacje prawne, stan i perspektywy rozwoju po integracji z Unią Europejską, Zeszyty Naukowe Akademii Ekonomicznej w Krakowie, 678.

[19] Organic farming. A guide on support opportunities for organic producers in Europe (2014). European Commission, Publications Office of the European Union, Luxembourg.

[20] Program Rozwoju Obszarów Wiejskich na lata 2014-2020 (2014). Ministerstwo Rolnictwa i Rozwoju Wsi, Warszawa.

[21] Willer H., Meredith S., Lernoud, J. (Eds.) (2016). Organic Farming in Europe. The World of Organic Agriculture. Statistics and Emerging Trends 2016, FIBL-IFOAM Report, Research Institute of Organic Agriculture (FIBL), Frick, and IFOAM - Organics International, Bonn. Available at: http:// www.organic-world.net/yearbook/yearbook-2016/pdf.html 10.05.2016. 